\section{An economic approach to peacemaking and peacekeeping}

Lloyd J. Dumas

Peace: rhetoric and reality

$\mathrm{W}$

hen Nigerian soldiers arrived in the capital city of Liberia in August 2003, much of the local population celebrated, some literally dancing in the streets. After years of bloody civil war, people were certainly not filled with joy at the sight of still more armed men in their country. What they were celebrating was the symbolic meaning of the arrival of the Nigerian peacekeepers the renewed hope of peace.

What does peace really mean? To the Liberians buoyed by the prospect that Nigerian peacekeeping forces would mean an end to years of brutal and brutalizing war, peace was not some idealized, esoteric, or complicated concept. It was the very pragmatic matter of having enough security to go about the ordinary business of life without the constant threat of murderous violence. They were not looking for Nirvana, just for the chance to live their lives.

Positive peace is more than the

This simple, straightforward absence of war. It is the presence of decency. definition of peace is what Johan Galtung referred to as "negative peace,” peace as the absence of war. But Galtung argued that there was a richer, more complex meaning of peace, "positive peace." For it is not bullets and bombs alone that kill and maim people. There is also such a thing as "structural violence," violence that is built into the structure of political, social, and economic systems. People who die of malnutrition in a world with more than enough food; who are blinded, crippled, or killed by preventable diseases; who become the targets of vicious crimes committed by desperate, marginalized people that have lost their sense of humanity in a world that does not welcome, value, or nurture them - these are not the victims of war. They are the victims of structural violence. Yet they are just as damaged, just as dead as those we count as war casualties. Positive peace is more than just the absence of war. It is the presence of decency.

What we mean by peacemaking and peacekeeping depends largely on what we mean by peace. If we are talking about peace as the absence of war, peacemaking is the process by which active hostilities between the parties at war can be halted. It may involve negotiations aimed at achieving anything from a temporary cease fire to a permanent cessation of hostilities between the warring parties. In conventional wars with clear battle lines, it could also mean inserting neutral outside military forces between warring factions to prevent them from getting at each other. Peacekeeping, on the other hand, means creating the conditions that prevent the renewed outbreak of a war that has at least temporarily ended. In the short term, neutral outside military forces can sometimes play a useful, even critical, role in this process by helping to police (and enforce) the conditions of cessation of armed conflict that the parties previously at war have agreed to honor. But in the long term, the peace that is being kept will only endure if the conditions that led to the outbreak of war have changed. This is much more likely to be achieved as a result of political, social, and economic change than because of the presence of armed peacekeeping forces.

The theory and techniques of economic analysis may be helpful to the process of making peace. A thoroughgoing cost-benefit analysis, for example, might help make it clear to each side that the full costs of continuing hostilities are likely to be far greater than the potential benefits (as is almost always the case). ${ }^{1}$ Economic agreements might also be part of the peacemaking negotiations process, ${ }^{2}$ particularly if economic factors were critical to the outbreak of hostilities in the first place. But the greatest contribution that economics can make to banishing the mass organized violence we call war lies in creating conditions that help keep the peace, especially in the long run. If we adopt the deeper, more comprehensive concept of positive peace - peace as the elimination of war and structural violence - it is even more obvious that economics has a powerful and critical role to play in building, solidifying, and maintaining peace.

\section{Building an international peacekeeping economy}

Most specialists in international relations tend to think of force or the threat of force as the most effective way of influencing behavior. Economists, on the other hand, tend to think of influencing behavior primarily through incentives. Economists assume that human behavior is driven by the
Specialists in international relations think of force as an effective way of compelling another actor's behavior. In contrast, economists think of incentives to induce others to voluntarily change their behavior. rational attempt to achieve explicit or implicit goals. For example, firms are typically seen as trying to maximize profits, while consumers are seen as trying to use the money they have available to buy goods and services that maximize their utility (pleasure or satisfaction). The key to influencing behavior is thus to create conditions in which the desired behavior becomes the behavior that the actors involved would voluntarily choose in pursuit of their own goals. 
(C) www.epsjournal.org.uk - Vol. 1, No. 2 (2006)

The economic approach to getting profit maximizing firms to invest more in new plant and equipment does not involve threatening management with jail if it does not comply. Instead, policy makers may offer an investment tax credit of, say, ten percent of the invested amount. That will lower the cost of buying new plant and equipment and raise its internal rate of return. Investment will be stimulated because the purchase of plant and equipment is now more profitable. Management does not have to be forced. It will invest more voluntarily because, under the new conditions, investing more helps achieve the goals that motivate the firm.

Looking at the world through an economist's eyes, there is no particular reason why this approach cannot be applied to influencing the behavior of nations. The problem is to identify a set of conditions that will generate positive incentives for nations to keep the peace and work out a set of policies and institutions capable of creating those conditions, not just on paper, but in the real world. That is a formidable task, though no doubt one that can be accomplished. The following pages briefly outline a few of the most critical conditions and also sketch some of the kinds of policies that might help to bring them about.

\section{Basic principles of an international peacekeeping economy}

In the late 1970s, Kenneth Boulding, former President of the American Economic Association, put forth what he referred to as the "chalk theory" of war and peace. ${ }^{3}$ A piece of chalk breaks when the strain applied to it is greater than its strength, i.e., its ability to resist that strain. In the same way, war breaks out among (or within) nations when the strain on the international (or domestic) system exceeds the ability of that system to withstand the strain. The key to establishing enduring peace is therefore to find ways of reducing the strain on the system or increasing its strength. Taken together, three basic principles presented here are an attempt to do both. They are fundamental to creating an international peacekeeping economy.

Principle I: establish balanced economic relationships

For years now, some have argued (despite the Bush administration's vehement protestations to the contrary) that the real reason the U.S. led a military invasion of Iraq in 2003 was the desire to control a vital economic asset, crude oil. There is nothing new in this argument. Over the centuries, many people have contended that most, if not all, wars are caused at least in part by economic factors. Others have claimed that economic relationships reduce the prospects for war, because they bind people together in common interest. ${ }^{4}$ Although it seems paradoxical, both arguments are correct. Economic ties between nations can foment war and worsen structural violence or help to keep the peace. It is the character of economic relationships, not their mere existence, that determines which it will be.
Relationships in which the flow of benefits is overwhelmingly in one direction tend to provoke hostility and conflict. Such relationships are inherently unfair. Even if those being exploited gain something from the relationship, the fact that the vast majority of the benefit flows in the other direction is bound to create or aggravate antagonisms. That is even more true if those being exploited are suffering a net loss. It is not necessary to look any farther than the revolution that gave birth to the United States for an example of the power of economic exploitation (or even the perception of such exploitation) to provoke antagonisms that can lead to war.

Exploitative relationships create incentives for disruption by those being exploited who then would like to find a way to destroy (or at least radically restructure) the relationship, and perhaps also to take revenge. Since they have little to lose and may actually gain if the relationship collapses, the exploited may well be ready to raise the intensity of whatever conflicts might occur, economic or otherwise, even to the point of war. If the exploiters come under stress from external sources, those being dominated will have a strong incentive to take advantage of the situation to try to break free. Knowing this will make the exploiters feel insecure and lead them to put an inordinate amount of effort and expense into maintaining control. This is often a much larger drain on the dominant nation and its economy than most people realize.

In balanced relationships, the flow of benefit is more or less equal in both directions. Because they are fair and mutually beneficial, balanced relationships do not provoke antagonism. On the contrary, as each party begins to perceive how much they are gaining, they start to see the well-being of the other party as in their own best interest. The mutual flow of benefits binds the parties together. Because the relationship benefits all participants more or less equally, they will all be more likely to look for ways of maintaining or strengthening it, out of self-interest. When conflicts occur, they will try to avoid disruption by settling them amicably. If their partners in the relationship come under stress from external sources, they will have an incentive to help relieve, rather than exacerbate, the pressure. In this situation, everyone in the relationship will feel more secure, and no one will feel the need to expend extra effort and expense just to keep it going. Put simply, a balanced relationship is a more efficient relationship: the benefits are achieved at a much lower cost. $^{5}$

Adam Smith saw all this clearly 230 years ago, though he was not particularly focused on the implications of balanced versus exploitative relationships for war and peace. In The Wealth of Nations (published in 1776), after a lengthy discussion in the context of the British colonial empire, Smith wrote: ${ }^{6}$ 
"Under the present system of management ... Great Britain derives nothing but loss from the dominion which she assumes over her colonies ... Great Britain should voluntarily give up all authority over her colonies ... [She] would not only be immediately freed from the whole annual expense of the peace establishment of the colonies, but might settle with them such a treaty of commerce as would effectually secure to her a free trade, more advantageous to the great body of the people [of Britain] ... than the monopoly which she at present enjoys.”

Balanced gain is important, but it is only one dimension of balanced relationships. If the process involved in making key decisions relative to the relationship is unbalanced, those with less input and control in the decision process may feel that they are unduly dependent on the good graces of the others. Even if the gains are currently balanced, believing that the terms of the relationship are subject to arbitrary, unilateral change creates insecurity and weakens commitment. When decisionmaking power is more equally shared, everyone involved has a feeling of ownership in the relationship. It is their property, not simply a gift someone has bestowed upon them and can just as easily withdraw. Every participant will therefore feel a greater sense of responsibility for taking care of the relationship, for insuring its continuation and success. This cannot help but strengthen the incentives of all participants to find peaceful ways of settling their conflicts with each other.

This may seem more like psychology than economics, but is in fact a central tenet of free market economics. It is precisely the reason so much emphasis is placed on the institution of private property. Because property can provide continuing economic benefits, the owner of private property has a strong personal incentive to maximize the flow of those benefits by caring for it properly and using it efficiently. This incentive would be dramatically weakened if the property were subject to sudden confiscation as a result of decisions made arbitrarily in a process over which the person using the property had no meaningful control.

The effectiveness of mutually beneficial, balanced economic relationships in keeping the peace is illustrated by the development and growth of the European Economic Community (EEC), the forerunner of today's European Union. Formed in 1957, by the early 1970s, the collection of nations that belonged to the EEC included Belgium, Denmark, France, Germany, Ireland, Italy, Luxembourg, the Netherlands, and the United Kingdom. These nations had not only fought countless wars with each other over the centuries (including World Wars I and II), some were major colonial powers that dominated and exploited the rest of the world. Yet today, if one were to ask the citizens of any of these countries the odds of their countries fighting a war with each other over the next fifty years, they likely would not consider this a sensible question.

It is not as if these nations no longer have conflicts with each other. In fact, they have many, economic and otherwise, some of them quite severe. For example, in the last few years alone, there were serious disagreements over the banning of British beef by other EU member states as a result of the outbreak of "mad cow" disease in Britain, ongoing squabbles over the adoption of the single European currency (the Euro), and a sharp split over the ongoing war in Iraq, with Spain initially and Britain still strongly in support, and France and Germany strongly opposed. But they all understand that they have too much to lose to let their disagreements get out of control. So they debate and argue, but they do not start shooting.

Since trade and investment are two of the most important economic relationships among countries, it is logical that the expansion of international trade and foreign investment has the potential for being a powerful force for keeping the peace. Both are clearly key elements of the much-discussed globalization process of the past few decades. Is the policy of embracing globalization then a path toward peace?

It could be, but only if the relationships established in the globalization process were balanced and mutually beneficial. Unfortunately, the globalization process, as shaped by key institutions like the World Trade Organization (WTO), has fallen short in two ways. First, because developing countries have been pressured to lower their trade (and investment) barriers, while more developed countries have continued to protect their agricultural sectors against competition from developing country produce, it has not reduced (and probably exacerbated) the imbalance of relationships between the more developed and less developed countries. Second, with a history of protected, closed-door meetings and secret negotiations, the WTO in particular has established decision-making procedures that are not inclusive enough to allow all major stakeholders to be party to the decision process, or even to know what is happening. Joseph Stiglitz, former chief economist at the World Bank, has written: ${ }^{7}$

“... to many in the developing world, globalization has not brought the promised economic benefits ... Despite repeated promises of poverty reduction made over the last decade of the twentieth century, the actual number of people living in poverty has actually increased by over 100 million ... [N]either has it succeeded in insuring stability. Crises in Asia and Latin America have threatened the economies and the stability of all developing countries.”

Stiglitz goes on to argue, ${ }^{8}$

"Globalization can be reshaped, and when it is, when it is properly, fairly run, with all countries having a voice in policies affecting them, there is a possibility that it will help create a new global economy in which growth is not only more sustainable and less volatile but the fruits of this growth are more equitably shared."

There are great potential benefits to reshaping globalization along lines that will 
democratize its decision-making processes and institutions and at the same time create much more balance in the gains of trade. But the benefits of this kind of restructured globalization are not confined to gains in economic equity and stability, as important as these matters are. More balanced trade, in the sense of both more equitable decision-making and more equal gain, is also a powerful force for peace.

\section{Principle II: emphasize development}

The poverty and frustration of so many of the world's people is a fertile breeding ground for violent conflict. There have been more than 120 wars since the end of World War II, taking more than twenty million human lives. Nearly all of them have been fought in developing countries.

People in desperate economic straits tend to reach for extreme solutions. They are much more easily manipulated by demagogues and seem easy prey to aggressors. People in good economic condition are much less likely to want to tear things up. Violent disruption is much more threatening to them because they have a lot more to lose. Therefore, emphasizing inclusive and widespread development is important to inhibiting both interstate and intrastate war. ${ }^{9}$

Development is also a useful counter-terrorist strategy. All but the craziest, most isolated terrorists (such as Ted Kacszinzki, the Unabomber) are to some degree dependent on, and are trying to build, support, at least for their cause if not their tactics. Most terrorists do not have the benefit of a wealthy patron such as Osama Bin Laden or the active support of a state, but even those that do must still recruit operatives. They also have to be able to move around, coordinate activities, take care of logistics, and find secure places to store matériel and to do whatever training or preparation is necessary without being detected by those who are trying to stop them. All of this is easier to do the wider their base of support.

To recruit reliable operatives and build the support networks they need, terrorist groups must have a cause that can convince people to engage in and actively or tacitly support acts of horrific violence they would not otherwise condone. This does not require that either the terrorists or their supporters be economically destitute. In fact, the group must have access to financial means and to people of some skill. But they need a powerful rallying cry to enable the group to recruit people who may not themselves be in desperate straights, and motivate them sufficiently to get them to take extreme, perhaps terminal risks.

Unfortunately, there seem to be a number of causes and circumstances that work well enough in practice. Most, if not all, involve calls to the service of some disadvantaged group or to some force greater than the individuals being recruited or solicited for support. As perverted as this may be, it is at base an appeal to heroism. If the individuals involved can be made to feel that by engaging in or supporting terrorism they become the avengers of a great wrong done to "their people," that they are the right hand of God fighting for the weak and downtrodden, then they can be made not only ready but eager to perpetrate or support horrific acts of violence against innocent people who have never directly done them any harm.

By raising the economic well-being and political status of the larger group of which the terrorists and their supporters feel part, development makes it substantially harder for terrorists to recruit operatives while at the same time weakening support among others who feel connected to that same larger group. It is not just that those who are part of a people in better economic and political condition are less marginalized and not so aggrieved, it is also that they have much stronger incentives to look for - and greater capability to find - less violent and more effective means of addressing whatever grievances they may have. Development can thus help dry up both the pool of potential terrorists and the wider support for terrorist groups critical to their continued operation.

The best way to deal with terrorism in the short run, and the only way to deal with the terrorism that arises from individual mental illness or group psychosis, is through first-rate intelligence and police work. But in the long run, economic and political development is the most effective way to undermine crucial elements of terrorist support systems. It is the only counter-terrorist strategy that directly addresses the marginalization, frustration, and humiliation of peoples that breed terrorism as well as many other forms of violence and inhumanity. It is not the whole answer to terrorism, but it is a very important part.

Unless substantial progress is achieved in generating sustained improvement in the material conditions of life for the vast majority of people in the developing countries, the prognosis for preventing war is poor. But with

such progress, it is not only possible to undermine terrorism and strengthen incentives to avoid war, it is also possible to do away with structural violence and build positive peace.

Principle III: minimize ecological stress

Competition for depletable resources generates conflict. The desire to gain (and if possible, monopolize) access to raw materials was one of the driving forces behind the colonization of much of the world by the more economically and militarily advanced nations in centuries past. This competition continues to bring nations, and sometimes sub-national groups, into conflicts of the most dangerous kind - those in which at least one party believes that the continued economic well-being, political sovereignty, or even survival of its people is at stake. 
Whether or not the desire to secure oil supplies was a key factor in motivating the U.S.-led invasion of Iraq in 2003, there is little doubt that conflicts in the Middle East would be much less likely to lead to military action by the major powers if it were not for Middle East oil. The considerable difference among the reactions of those powers to aggression in Bosnia, genocide in Rwanda, slaughter in Sudan (Darfur), and hostility in Iraq may have a variety of causes, but oil is certainly one of them.

Water and air do not recognize the artificial lines that we have drawn on the earth to separate ourselves from each other. Environmental damage knows no national boundaries and can also be an important source of international conflict. That is illustrated both by acute environmental disasters such as the nuclear power accident at Chernobyl and such chronic problems as acid rain. Widespread international hostility to the U.S. decision to abandon the Kyoto accords, for example, is in no small measure due to the dramatic effect that continued transboundary pollution by greenhouse gases is likely to have on climate change, with the consequence of imposing potentially enormous long-run costs on the world economy. According to estimates by Janet Abramovitz, the worldwide economic costs of global climate change are expected to be US\$300 billion per year by 2050. ${ }^{10}$ James Titus of the U.S. Environmental Protection Agency estimated that the costs of a doubling of carbon dioxide levels to the United States alone could be as high as US\$351 billion per year by 2060, based on models developed by both the Goddard Institute for Space Studies and the Princeton Geophysical Fluid Dynamics Laboratory. ${ }^{11}$

Transborder pollution itself may not lead to war, but it has already generated considerable conflict and has the prospect of generating a great deal more. Every additional source of tension contributes to the strain on the international system and therefore to the likelihood that other sources of conflict will lead to the eruption of violence. Put simply, the greater the load on the camel's back, the more likely that the next straw will break it.

Some have argued that the expansion of economic activity itself is inconsistent with maintaining environmental quality, that modern production techniques and consumption activities generate an unavoidable degree of ecological stress. There is an element of truth in this. Still, the levels of economic well-being to which the people of the more developed countries have become accustomed can be maintained, improved, and extended to people of the less developed nations without generating current levels of environmental damage. Accomplishing this feat requires (1) a great deal more attention than is currently being paid to the efficient use of natural resources, (2) the development and extensive use of pollution-abating technologies and procedures, and (3) a substantial shift toward qualitative, rather than quantitative economic growth, particularly on the part of the more developed countries.

The efficient use of natural resources involves more intensive and widespread recycling of nonrenewable materials, efficiency improvements in the design and operation of energy-using systems, and greater use of ecologically benign, renewable energy and material resources. Recycling of nonrenewable materials dramatically reduces the rate of their depletion, transforms solid wastes into useful material, and saves energy, thus reducing both the rate of depletion of nonrenewable energy resources and the pollution associated with their use. Three decades ago, I estimated that a combination of improved design and changes in the operation of energy-using systems could reduce energy consumption in the United States by 30 to 50 percent without sacrificing living standards. ${ }^{12}$ And of course, the further development of renewable resources will provide supplies of energy and materials that can sustain economic activity indefinitely.

The development and use of pollution-abating technologies and procedures is two-sided. It involves better filtration, waste treatment, and other after-the-fact cleanup. But it also involves the development and use of less environmentally damaging production and consumption technologies, ultimately working toward mimicking natural ecological systems in which the waste of one process becomes the feedstock of the next in an endless cycle.

Finally, to conceive of economic growth mainly in quantitative terms is foolish and unnecessary. Standards of living are also raised, sometimes more effectively, by improvements in the quality of goods and services. Shifting attention to qualitative growth will allow developed nations to reduce their appetite for nonrenewable resources, making their continued growth indefinitely sustainable. It will also reduce environmental pollution and create space for the quantitative expansion of goods and services still required in many less developed nations.

To the extent that we follow strategies such as maximizing energy efficiency, developing renewable, ecologically benign energy and material resources, and conserving depletable minerals by recycling, we will not only improve the quality of the environment, but also reduce these sources of international conflict and strain on our ability to keep the peace.

\section{Conclusion}

Economics has been called "the dismal science," and dismal it has often been, from the depressing eighteenth century musings of Thomas Malthus to the thinly disguised social Darwinism of heartless twentieth century “trickle down” economics. It seems an odd place to look for hope.

Yet there is great hope in the perspectives and strategies that economics has to offer. Early in the twenty-first century, we find ourselves in the midst of a dramatic, decades-long reshaping of the international economic and political landscape. By learning to put aside the idea that force and threat of force is the most effective means affecting international behavior and adopting instead the economist's perspective that behavior is best influenced through incentives and creating opportunities for mutual gain, we can guide the change that is swirling all around us in more constructive 
directions. We can create a web of international economic relationships that not only serves our material needs, but also provides strong positive incentives to make and keep the peace. And rather than a world of deepening inequality and growing insecurity, we can build a world that is at once more equitable, more prosperous, and more secure.

\section{Notes}

\section{Lloyd J. Dumas is Professor of Economics at the University of Texas, Dallas.}

1. This is not to deny the possibility that there are some individuals or groups on one or another side that gain from violent conflict and therefore have an incentive to keep it going. For an interesting empiricallybased analysis of this possibility with respect to civil war, see, e.g., Collier (2000).

2. The Camp David Accords that brought peace between Israel and Egypt in 1978 included important economic agreements. These were commitments by the United States to provide substantial foreign aid to both parties in order to allay a variety of their concerns.

\section{Boulding (1978).}

4. For a history of economic theories of peace and war, see Coulomb (2004).

5. A classic article on trade, war, and peace is Polachek (1980). An update with the latest literature review is forthcoming in Polachek and Seiglie (2007).

6. Smith (1937 [1776], pp. 581-582).

7. Stiglitz (2002, pp. 5-6).

8. Stiglitz (2002, p. 22)

9. The exploitation of nonrenewable natural resources - what Paul Collier has called "lootable resources" - can be a strong spur to violent conflict and war within a nation (see Collier, 2000, and also de Soysa, 2000). But economic growth that is largely or solely dependent on exploiting such resources is not the same as development. Real development implies building a stronger, more diversified economic base. It also requires that the gains derived from economy expansion be far more widely and equitably distributed among the population than is typical of economies built on the exploitation of one or two nonrenewable resources.

10. Abramovitz (2001, p. 38), citing the Munich Reinsurance Company and the U.N. Environmental Program. Also see Worldwatch Institute (2002, p. 41).

11. Titus (1992, pp. 1 and 6). Titus' estimates of the cost of climate change to the U.S., based on the models cited, range from as low as US\$37 billion to as high as US\$351 billion per year, depending on the model used and the precise scenario followed.

\section{References}

Abramovitz, J.N. 2001. Unnatural Disasters. Worldwatch Paper 158. Washington, DC: Worldwatch Institute.

Boulding, K.E. 1978. Stable Peace. Austin, TX: The University of Texas Press.

Collier, P. 2000. "Doing Well Out of War," pp. 91-112 in M. Berdal and D. Malone, eds. Greed and Grievance: Economic Agendas in Civil Wars. Boulder, CO: Rienner.

Coulomb, F. 2004. Economic Theories of Peace and War. London: Routledge.

DeSousa, I. 2000. “The Resource Curse: Are Civil Wars Driven by Rapacity or Paucity?” pp. 113-135 in M. Berdal and D. Malone, eds. Greed and Grievance: Economic Agendas in Civil Wars. Boulder, CO: Rienner.

Dumas, L.J. 1976. The Conservation Response: Strategies for the Design and Operation of Energy-Using Systems. Lexington, MA: Heath.

Polachek, S. 1980. "Conflict and Trade.” Journal of Conflict Resolution, Vol. 24, pp. 55-78.

Polachek, S. and C. Seiglie. 2007. “Trade, Peace, and Democracy,” in T. Sandler and K. Hartley, eds. Handbook of Defense Economics, vol. 2. Amsterdam: Elsevier.

Smith, A. 1937. [1776]. The Wealth of Nations. New York: The Modern Library, Random House.

Stiglitz, J.E. 2002. Globalization and Its Discontents. New York: Norton.

Titus, J.G. 1992. "The Costs of Climate Change to the United States," in S.K. Majumdar, et.al, eds. Global Climate Change: Implications, Challenges, and Mitigation Measures. Philadelphia: Pennsylvania Academy of Sciences.

Worldwatch Institute. 2002. State of the World 2002. Washington, DC: Worldwatch Institute.

12. Dumas (1976). 